ISSN 1991- 8690

website: http://jsci.utq.edu.iq

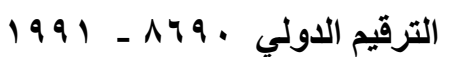

Email: utjsci@utq.edu.iq

\title{
Detection of Entamoeba histolytica antigen in stool specimens by using ELISA in Basrah province
}

\author{
Aseel J. Al-Yaquob \\ Biology Department- Colloge of Education - University of Basrah
}

\begin{abstract}
In the present study, we have been used an Enzyme Linked Immunosorbent Assay

( ELISA) for detection of E. histolytica $\backslash E$. dispar and comparing it with microscopic examination Sixty five samples were examined by ioden staining was positive in $35(53.6 \%)$ then these iodine positive samples examined by ELISA a lotof which $33(94.2 \%)$ were positive in the mean time $4(13.33 \%$ ) were positive in ELISA although that they were negative in microscopic exam.It can be concluded that microscopical examination has low sensitivity and specificity in comparision with ELISA.
\end{abstract}

Key word: E. histolytica, ELISA, Basrah 


\section{$\underline{\text { Introduction }}$}

Amoebiasis is an infection of the large intestine caused by the parasitic protozoan E.histolytica [ 1 ]. It is well known that annually 500 million individuals are infected world wide, resulting in 100000 deaths [2].However, the true distribution of the disease is not clear in Iraq especially in Basrah province.

E.histolytica actually indistinguishable species, E.histolytica can cause invasive intestinal and extra intestinal disease, while E.dispar and other species can not [ 3 ].Thus the correct identification of this parasite is very important since E.histolytica is only species with in the genus Entamoeba required treatment.

Diagnosis of E.histolytica is usually based on microscopic examination of protozoan morphology [4 ].However, it reach about $60 \%$ sensitivity and can give false positivity due to misidentification of nonpathogenic Entamoeba species [ 5 ].

Methods for antigen detection of E.histolytica by using ELISA in stool and polymerase chain reaction (PCR) have evaluated as diagnostic tools [ 2 ].

The present study have been designated to detect E.histolytica by using ELISA.

\section{Materials and Methods}

Stool specimens were collected from patients with blood and $\backslash$ or mucus diarrhea at December 2008 and April 2009 at the Al- Fayha hospital in Basrah province.

A total of 65 stool specimens were iodine stained and examind by microscopy according to

[ 3 ]. E. histolytca antigen (REF6004,Ludwig - Erhared - Ring ,15827 Dahlewitz,GERMANY).Detection was performed by ELISA according to manufacturers instruction. Briefly , 96-well microtiter ELISA plates were coated with polyclonal antibodies to E.histolytica peptide 1 (rabbit).Stool specimens were diluted 1: 10 in dilutents provided with the kit. Assay microtiter wells were incubated with $100 \mu$ diluted samples and two drops of negative control and two drops of positive control, seal plates incubated at $30 \mathrm{~min}$ at room temperature $(20-25 \mathrm{C} \dot{ })$. The contents of the well strips were decant and were washed five time by using $300 \mu \mathrm{l}$ of wash solution.After that two drops of conjugate added and the strip was incubated at room temperature .The contents decant, two drops of substrate solution was added and the strip was incubated at room temperature in the dark at 10 min.Following the incubation ,the reaction was stopped by adding two drops of stop solution to each well and mix gently, the absorbance was measured at $450 \mathrm{~nm}$. The assay run was correct if the mean OD of the negative control is $\leq 0.2$ or the mean of the positive control is $\geq 1$.

\section{$\underline{\text { Results }}$}

Out of 65 stool samples examind microscopically 35(53.8\%) were infected with E.histolytica and E.dispar complex parasite. The examination of the 35 positive samples by using ELISA test revealed that $33(94.2 \%)$ were positive for E.histolytica while after examing the rest 30 negative samples were given $4(13.33 \%)$ ( Table 1$)$.

Evaluation of the sensitivity and specify of microscopic exam and ELISA test revealed that $24.6 \%, 24.6 \%, 94.2 \%$ and $100 \%$ respectively.

Comparison of characteristic stool samples by using microscopical and ELISA revealed that $5(14.4 \%)$ contained blood , 2( 5.7\% ) contained blood and mucus , 4(11.4\%) contained mucus and $3(8.5 \% \%$ ) were watery ( Table 2 ). 
Table (1)Comparsion of samples by microscopical examination and ELISA results

\begin{tabular}{|c|c|c|c|}
\hline \multirow{2}{*}{$\begin{array}{c}\text { Direct smear } \\
\text { positive }\end{array}$} & ELISA positive & ELISA negative & Total \\
\cline { 2 - 4 } & 33 & 2 & 35 \\
\hline $\begin{array}{c}\text { Direct smear } \\
\text { positive }\end{array}$ & 4 & 26 & 30 \\
\hline Total & 37 & 28 & 65 \\
\hline
\end{tabular}

Table (2)Comparsion of characterstic stool samples by microscopical and ELISA examination

\begin{tabular}{|c|c|c|c|c|c|}
\hline \multirow{2}{*}{ characteristic } & \multirow{2}{*}{ No. of samples } & \multicolumn{2}{|c|}{ Microscopical exam } & \multicolumn{2}{c|}{ ELISA test } \\
\cline { 3 - 6 } & & positive & negative & positive & Negative \\
\hline Blood & 5 & 5 & - & 5 & - \\
\hline Blood mucoid & 2 & 2 & - & 2 & - \\
\hline Mucoid & 4 & 4 & - & 4 & - \\
\hline semisolid & 43 & 21 & 22 & 24 & 19 \\
\hline Watery & 3 & 3 & - & - & 3 \\
\hline Pus cell & 2 & - & 2 & 2 & - \\
\hline Solid & 6 & & 6 & & 6 \\
\hline Total & 65 & 35 & 30 & 37 & 19 \\
\hline
\end{tabular}

\section{$\underline{\text { Discussion }}$}

The recognition of E.histolytica and E.dispar as different species has provided important insights into the epidemic behavior of amoebiasis in the world [ 6 ] and had important epidemiological and clinical implications [ 7 ].

Antigen detection test are reported to be more sensitive and specific than direct microscopic examination [ 1 ], Detection of antigen in the stool and serum is revolution in the diagnosis of E.histolytica due to the easy of use, high sensitivity and specificity of available test 8 ].Present study represent the first trying in Basrah province to specific identification of E.histolytica by using ELISA test.

In the present study microscopy had been $24.6 \%$ sensitivity and specificity respectively, which were similar to that reported by [ 4 ] when they mentioned that sensitivity ranged between $20 \%$ to $60 \%$ and $10 \%$ to $50 \%$ specificity , and the variation in the range of sensitivity and specificity may be due to effects of several factors which includes: lack of well trained microscopists ,delayed delivery to the laboratory and difficulty in differentiation between nonmotile trophozoites and polymorphonuclear leukocytes[ 9 ].

ELISA test has $94.2 \%, 100 \%$ sensitivity and specificity respectively and this agreement with[ 1 ] that they found the sensitivity of this method was 95\% [ 10 ].[ 11, 12 ] and [ 13 ], found that sensitivity and specificity were $87 \%, 84 \%, 83 \%$ and $92.5 \%$ respectively and this 
different may be due to they using of monoclonal antibody for detection of antigen in stool while in the present study polyclonal antibody have been used.

It is well known that laboratory examination plays a major role in the diagnosis of intestinal amoebiasis, as well as the history of patient.

Although direct microscopic examination is unexpensive compared to antigen detection test, the subjectivity of the test ,the requirement for experienced microscopists due to the difficulty in differentiating the parasites from leucocytes and other intestinal parasites and its inability to differentiate pathogen species from nonpathogenic forms limits its reliability [14 ].The PCR technique is time consuming, expensive and therefore not well suited for use in developing countries where amoebiasis is prevalent [1].The antigen detection test has been shown to be suitable for the diagnosis amoebiasis in endemic areas [15 ]due to the test is rapid and simple and dose not require any special equipment, is presently the only practical means for diagnosis of E.histolytica infection [1].

\section{References}

1-Haque , R. ;Alilk , M. ;Akther , S. and Petri , Jr. W. A. ( 1998 ). Comparison of PCR , isoenzyme analysis and antigen detection for diagnosis of Entamoeba histolytica infection. J. Clin. Microbiol., $36: 449-452$.

2-Samie , A. ;Obi , L. C. ; Bessong , D. O. ; Scroup , S. ; Houpt, E. and Guerrant , R. L. ( 2006 ). Prevalence and species distribution of $E$. histolytica $E$. dipar in the Venda region, Limpopo ,South Africa . Am. J. Trop. Med. Hyg., 75 :565 - 571 .

3-Ackers, J. P. ( 2002 ). The diagnostic implications of separation of Entamoeba histolytica and $E$. dispar. J. Biosci., 27 (6) : $573-578$

4-Tanyuksel , M. and Petri, Jr. W. A. ( 2003 ). Laboratory diagnosis of amoebiasis . Clin. Microbiol. Rev., $16: 713-729$.

5-Haque ， R. ;Mondal,D.;Duggal,P.;Kabir,M.;Roy,S.;Farr,B.M.;Sack,R.B. and Petri ， Jr. W. A. ( 2006 ). Entamoeba histolytica infection in children and protection from subsequent amebiasis.Infect.Immun.74:904 - 909.

6-Walsh,J.A.( 1986 ).Problems in recognition and diagnosis of amoebiasis,Estimates of the global magnitude of morbidity and mortality.Rev.infect.Dis.8:228-238.

7- Diamond , L. S. and Clark , C. G. ( 1993 ). A redescription of Entamaeba histolytica Schaudinn , 1903 (Emended Walker,1911) separating it from Entamaeba dipar Brumpt, 1925 . J. Eukaryot. Microbiol. , 40: 340 - 344.

8-Ravdin , J. I. ( 2000 ). Entamaeba histolytica ( amoebiasis ). In : Mondell , G. L. ; Bennett and Dolin , R. ( eds. )( 1999 ). Principles and practice of infection disease . 5th ed. Churchill Livingstone, Inc. Philadelphia ,USA : 2798 -2810.

9-Garcia , L. S. and Bruckner, D. A. ( 1997 ). Dignostic medical parasitology . $3^{\text {rd }}$ ed. Asm Press , Washington , D. C., USA.

10-Haque , R. ; Neville, M. ; Hahn , P. and Petri , Jr. W. A. ( 1995 ). Rapid diagnosis of Entamoeba infection by using Entamoeba and Entamoeba histolytica stool antigen detection kits .

J. Clin. Microbiol., $33: 2558$-2561 .

11-Abd - Alla , M. ; Jackson , T. and Ravdin , J. I. ( 1998 ). Serum IgM antibody response to the galactose - inhibitable adherence lectin of Entamoeba histolytica . Am. J. Trop. Med. Hyg., 59 : $431-434$.

12-Abd - Alla , M. ; Jackson , T. ; Readdy , S. and Ravdin , J. I. ( 2000 ). Diagnosis of invasion amoebiasis by enzyme - linked immunosorbent assay of saliva to detect amoebic lectin antigen and anti - lectin immunoglobuline $G$ antibodies . J. Clin .

13-Hatam, Microbiol. $38: 2344$ - 2347 .

Gh. ; Khorrami , H. R. ; Sahebani , N. and Sarkari , B. (2007). Evaluation of 
enzyme - linked immunosorbent assay (ELISA) and dot ELISA for diagnosis of amoebiasis. Shiraz. E. Med. J., 8:1 - 9.

14-Delialioglu , N. ; Aslan , G. ; Sozen , M. ; Babur , C. ; Kanik , A. and Emekads , G.( 2004) .Detection of Entamoeba histolytica $/ E$. dispar in stool specimens by using enzyme -linked immunosorbent assay . Mem. Inst. Oswaldo , Cruz, Rio , Dejaneiro , 99 : 769 772 .

15-Abd - Alla , M. ; Jackson , T. and Ravdin , J. I. ( 1998 ). Serum IgM antibody response to the galactose - inhibitable adherence lectin of Entamoeba histolytica. Am. J. Trop. Med. Hyg., $59: 431-434$.

\title{
الكثف عن مستضد الاميبا الحالة للنسيج Entamoeba histolytica في نماذج الغائط باستعمال اختبار ELISA في محافظة البصرة
}

\author{
اسيل جمعة اليعقوب \\ قسم علوم الحياة ـ كلية التربية - جامعة البصرة
}

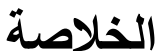

تم في الدراسة الحائية استعمال فحص الامتصاصية المناعية المرتبطة بالاتزيم ELISA ) قي الكثف عن الاصابة بطقيلي الاميبا الحالة للنسيج E. histolytica ومقارنته مع الفحس المجهـري ل للفائط ( بطريقة المسحة المباشرة ).

اثشارت نتائج الدراسة الحالية الى كثف اصابة هب ( ؟, به \% ) من اصل هب عينة غائط تم فحصها مجهريا باستعمال صبغة اليود ، وعند استعمال اختبار ELISA كثفت اصابة بr ( r, \&9 \% ) بـالطفيلي

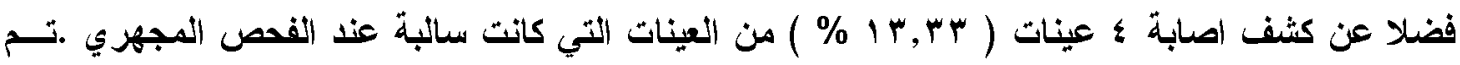
الاستتناج بعد هذه الارلة اسن حساسية وخصوصية الفحص المجهري القل من حساسية وخصوصية اختبار

.ELISA 